\title{
LIBIROS NUEVOS
}

Los libros que a continuación enumeramos han aparecido recientemente. y sus autores han tenido la cortesía de enviarlos a nuestra Revista o a la Universidad.

En el próximo número de AAtenea, publicaremos reseñas criticas acerca de algunos de ellos.

- Guillermo Subercaseaux. Historia de las doctrinas económicas en América $y$ en especial en Chile. Santiago de Chile; Soc. Imprenta y Lit. Universo: 1924.

- Alejandro Vicuña. Por la Jusficia y la Paz (Arfículos de prensa: 1923-1924). Santiago de Chile; Imp. y Lit. ¿La Ilustraciónı: 1924.

-Rocesín. La Biblioterapia. Notas humoristicas. sátiras y prosas breves. Editorial Nascimento: 1924.

-Roberto Munizaga Aguirre. La voz ferviente (Poemas). Editorial Nascimento; Santiago, Chile.

-Jorge González B. El Poema de las tierras pobres. Soc. Imp. y Lit. Universo: Santiago.

- Daniel Samper Ortega. En el Cerezal; (Acuarelas literarias de la Sabana de Bogotá). Editorial de Cromos; Bogotá; 1924.

-ANGel M. PARedes. Sociologia General. Quito.

_LEOPOLdo Lugones. Filosoficula. Buenos Aires. Editorial Babel.

- Nicolás Coronado. Desde la plafea. Buenos Aires. Editorial Babel.

-Samuel Glusberg. La levita gris. Buenos Aires. Editorial Babel. 